\title{
Developing a parent material for breeding forage rye in conditions of Bashkortostan
}

\author{
A. Kh. Shakirzyanov ${ }^{1}$, I. M. Nikonorova ${ }^{1 区}$, V. A. Agafonova ${ }^{1}$ \\ ${ }^{1}$ Bashkiria Research Agricultural Institute, Ufa Federal Research Center of the Russian Academy of Sciences, \\ Ufa, Russia \\ 凶E-mail: ilyusya.nikonorova@mail.ru
}

\begin{abstract}
The purpose of the research is to create source material for breeding forage rye that combines stable productivity over the years, high protein content in the grain, and low content of water-soluble pentosans. The object of research was winter rye. Research methods Research on these tasks was carried out in 2016-2018 in the conditions of the South-Western Urals using generally accepted methods. The predecessor is dead fallow. Soil is chernozem with a predominance of leached, typical and carbonate varieties with the following agrochemical indicators: humus content in the topsoil $-7-9 \%, \mathrm{pH}_{\text {value }}-7.2-7.6$, total nitrogen in the arable layer of the soil $-0.4 \%$, mobile potassium and phosphorus (according to Machigin) - respectively $20.5 \mathrm{mg} / 100 \mathrm{~g}$ and $10.2 \mathrm{mg} / 100 \mathrm{~g}$ of dry soil, calcium $-5.6 \%$. The recommended rate of mineral fertilizers is $\mathrm{N}_{60} \mathrm{P}_{60} \mathrm{~K}_{60}$ Scientific novelty. For the first time, 3 promising winter rye varieties selected in the Bashkir scientific research Institute and 2 samples of the All-Union Research Institute of Plant Breeding were studied in climatic conditions of south-western Cis-Ural. The content of water-soluble polysaccharides (WSP) and the water extract viscosity (WEV) were evaluated. The breeding value of plants was studied. Results The main indicators of the nutritional quality of winter rye grain are found to depend on both the variety (genotype) and the influence of external conditions (phenotype). It was detected that the content of water-soluble polysaccharides and the dynamic viscosity of the grain meal water extract are in a linear relationship $(r=0.98)$. They are unstable indicators and have a variable character. There are two varieties (Kombaynnyay 3 i Krupnozernaya 2 ) with the lowest WSP and WEV values and a high protein content in the grain. They can serve as source material to develop fodder crops in conditions of the Republic of Bashkortostan. The rye WEV was found to increase significantly in dry years, and decrease in wet years. The comparative evaluation of grain crops showed that the WEV of winter rye exceeded that of winter wheat by 3.5 times, spring wheat by 3.7 times, and winter triticale by 3.1 times. It was found that the samples with lower WSP and WEV indicators had small grains, low grain unit and higher protein content.
\end{abstract}

Keywords: winter rye, water extract viscosity, water-soluble polysaccharides, weight per 1000 kernel, feed quality.

For citation: Shakirzyanov A. Kh., Nikonorova I. M., Agafonova V. A. Developing a parent material for breeding forage rye in conditions of Bashkortostan // Agrarian Bulletin of the Urals. 2020. No. 08 (199). Pp. 19-24. DOI: ... (In Russian.)

Paper submitted: 03.06.2020.

\section{Introduction}

Rye is a multipurpose crop. Winter rye is one of the most important agricultural crops because of its high adaptive capacity and stable grain yield. It is the best precursor for many crops. Winter rye has a beneficial agrotechnical effect. Due to its vigorous tillering and rapid growth, it suppresses the growth of many weeds. It is grown for rye bread and fodder production as well as a technical raw material in the starch, alcohol and distillery industries [1, p. 225]. Winter rye is a crop that can be grown continuously on the same land for many years. Among other grain crops, it has the lowest requirements for soil fertility, fertilizers, herbicides and pesticides, which allows to classify it as a crop of low economic risk. In modern environmental and economic conditions, it is promising to make biofuels from plants. Winter rye is the most suitable and beneficial crop for these purposes. Its main advantage is that in addition to grain, you can use its waste and crushed straw. Winter rye is one of the best cover crops in terms of protecting the soil from erosion. Winter rye makes it possible to reduce the load on farm machinery during spring crop planting and harvesting. This makes it possible to reduce the number of agricultural machines in a farm, having a positive impact on production efficiency as a whole [2, p. 412].

Winter rye is a plant that can be cultivated in a moderately cold climate. It is the least demanding to soil and climate conditions. In autumn, rye rapidly produces a ground cover and develops a powerful root system. Its biomass is comparable with the ground part of the plant [3, p. 995]. Thanks to this, rye has the ability to maximize the use of autumn-spring moisture, and quickly resume vegetation in spring. Due to the fact that the extensive root system of rye penetrates to a great depth in autumn, it can use nutrients from hard-to-reach compounds [4, p. 19].

However, with all these advantages, the demand for rye grain is extremely low being the reason for the reduced cultivated areas both in Russia and around the world.

According to the Russian Land Statistics the cultivated area for rye in 2019 was 850,3 thousand hectares, which is 
$13,2 \%$ less than in 2018 . The rye acreage decreased by $54.7 \%$ over the past 5 years, $60.4 \%$ for 10 years, $76.6 \%$ by 2001 . Winter rye acreage in the Republic of Bashkortostan in 2019 was 119.2 thousand hectares, which is $13.7 \%$ of the total rye area of the Russian Federation.

The gross harvest of rye in the Russian Federation in 2019 amounted to 1,428 . 6 thousand tons, being $25.4 \%$ less than in 2018 . The yields decreased by $56.5 \%$ over 5 years, $67.0 \%$ for 10 years, $78.5 \%$ by 2001 . The Republic of Bashkortostan is leading among other Russian regions in terms of gross rye yields being 229.3 thousand tons (16.0 \% of the total yield).

One of the main reasons for the decline in rye planting is the extremely low demand for rye grain from its main consumers, both in the domestic and global markets. The subsequent reduction of rye acreage resulted from plant lodging, significant crop failure during overwintering, and the relatively low purchase price for rye grain [5, p. 38], [6, p. 302].

Currently, one of the most pressing problems is the expanded use of winter rye grain. It is impractical to strive to create all-purpose varieties of rye. It is necessary to create varieties for a specific use, which will fully meet the needs of the consumer. The priority and main task of modern selection of winter rye is to create varieties of different uses, suitable for baking, production of wine, starch, alcohol, malt, syrup, pharmaceuticals, various biopolymers, as well as for animal feed.

Expanding the range of rye grain products will increase demand for it, since they have the most valuable properties for healthy nutrition and are of particular interest as raw materials for dietary products. Undoubtedly, bakery products, as well as diabetic and dietary rye products will have a great purchasing demand [7, p. 6490].

The use of rye grain for animal feeding will strengthen the feed base and provide rational feeding of farm animals. About $8-12 \%$ of the gross yield of winter rye grain is used in production of mixed fodders. Most of the crop are used for early green fodder, as well as for hay, haylage and silage making. In the diet of animals, rye is no more than $20 \%$ of the grain weight.

The main indicator of the nutritional value of grain is the protein content that is, the more protein, the higher the feed quality of rye grain $[8$, p. 33]. Protein is essential for growth and development. They perform enzymatic, building, and regulatory functions in the cell. Protein is of great importance: its reduction in the diet to $3 \%$ of the recommended rates leads to an enzyme deficiency, having negative effect on the absorption of important nutrients [9,p.144]. The protein content of the grain depends on both the variety and the conditions of cultivation. Rye grain contains $9-17 \%$ protein, $52-63 \%$ starch, 1.6-1.9\% fat. The nutritional value of rye protein is superior to other cereals. Rye protein is also rich in lysine, threonine, phenylalanine, arginine, and is more balanced in amino acid composition. It is rich in vitamins, micronutrients and biologically active substances that are necessary for animal nutrition. All these advantages undoubtedly attract livestock breeders. In addition, the price of forage rye is relatively low. However, with all these advantages, rye grain isn't used widely for animal feed. Due to its low taste quality, animals do not readily eat it, and the content of a complex of harmful substances negatively affects digestion. In this regard, the value of winter rye as a forage crop is small. The main reason is that rye contains antinutrients negatively affecting uptake of rye grain nutrients by animals [10, p. 43].Rye grain for fodder can be used with special enzyme preparations that hydrolyze pentosans or after pre-preparation (extrusion, flattening, canning). However, this leads to an increase in the cost of fodder by more than $30 \%$. In recent years, it has been proved that the digestion of animals is worsened by pentosans, polymers that together with cellulose, lignin and minerals form the cell walls, intercellular shells of grain, and the thick cell walls of the endosperm aleurone layer. Pentosans, like starch and cellulose, have a high molecular weight and a branched structure of molecules. Nevertheless, unlike starch and cellulose, formed from the remains of glucose molecules (having six carbon atoms in the molecules), pentosans are formed from the remains of arabinose and xylose molecules (having five carbon atoms in the molecules). Hence, there is another name of pentosans - arabinoxylans. This is the very group of active pentosans that have a negative effect on the digestion of domestic animals [11, p. 1045]. The use of winter rye grain in animal feeding is limited due to the content of pentosans in them [12, p. 432].

The cell walls of the grain shells and the aleurone layer of rye are much thicker than in wheat, so the total content of pentosans in rye is higher ( $7-13 \%$ in rye, $5-7 \%$ in wheat ). The content of water-soluble or active pentosans in rye grain is three times higher than in wheat $(1.5-3.0 \%$ in rye, $0.5-1.5 \%$ in wheat). Pentosans have the ability to absorb and retain large amounts of water, forming mucus. When grinding grain, pentosans are released, entering the digestive tract as part of the feed, absorb water and form a mucus that covers the food lump and the walls of the stomach and intestines, preventing food digestion. The nutritional value of rye grain can be increased if the content of water-soluble pentosans is reduced by three times. Along with this, the mixed feed industry needs grain with a high protein content.

The content of water-soluble pentosans (WSP) in grain and the water extract viscosity (WEV) of grain meal of different varieties of winter rye (2016-2018)

\begin{tabular}{|c|c|c|c|c|c|c|c|c|}
\hline \multirow{2}{*}{ Variety } & \multicolumn{4}{|c|}{ WSP, \% } & \multicolumn{3}{c|}{ WEV $\boldsymbol{c S t}$} \\
\cline { 2 - 10 } & $\mathbf{2 0 1 6}$ & $\mathbf{2 0 1 7}$ & $\mathbf{2 0 1 8}$ & Average & $\mathbf{2 0 1 6}$ & $\mathbf{2 0 1 7}$ & $\mathbf{2 0 1 8}$ & Average \\
\hline Chulpan 7 & 2.54 & 1.69 & 2.92 & $\mathbf{2 . 3 8}$ & 33.4 & 28.6 & 38.2 & 33.4 \\
\hline Chulpan 9 & 2.97 & 2.10 & 2.51 & $\mathbf{2 . 5 3}$ & 36.6 & 25.2 & 29.8 & 30.5 \\
\hline Pamyati Kunakbaeva & 3.06 & 2.96 & 2.90 & $\mathbf{2 . 9 7}$ & 45.4 & 44.6 & 45.0 & $\mathbf{4 5 . 0}$ \\
\hline Kombaynnyay 3 & 1.50 & 1.47 & 1.48 & $\mathbf{1 . 4 8}$ & 8.4 & 5.6 & 6.7 & $\mathbf{6 . 9}$ \\
\hline Krupnozernaya 2 & 1.58 & 1.43 & 1.52 & $\mathbf{1 . 5 1}$ & 5.5 & 5.3 & 8.5 & $\mathbf{6 . 4}$ \\
\hline
\end{tabular}


Water extract viscosity (WEV) in different crop varieties (average for 2016-2018, cSt)

\begin{tabular}{|c|c|c|c|c|c|c|c|}
\hline \multicolumn{2}{|c|}{ Winter rye } & \multicolumn{2}{|c|}{ Winter wheat } & \multicolumn{2}{|c|}{ Spring wheat } & \multicolumn{2}{|c|}{ Winter triticale } \\
\hline Variety & $W E V, c S t$ & Variety & $W E V, c S t$ & Variety & $W E V, c S t$ & Variety & $W E V, c S t$ \\
\hline Chulpan 7 & 33.4 & Bashkirskaya 10 & 6.82 & Ekada 109 & 6.85 & $\begin{array}{c}\text { Bashkirskaya } \\
\text { korotkostebel'naya }\end{array}$ & 7.90 \\
\hline Chulpan 9 & 30.5 & Bashkirskaya 3 & 6.93 & Ekada113 & 6.68 & Bashkirskaya 3 & 6.98 \\
\hline $\begin{array}{c}\text { Pamyati } \\
\text { Kunakbaeva }\end{array}$ & 45.0 & Lyutestsens 9 & 7.26 & Ekada & 6.73 & Privada & 8.10 \\
\hline Kombaynnyay 3 & 6.9 & $\begin{array}{c}\text { Volzhskaya } \\
\text { kachestvennaya }\end{array}$ & 6.98 & $\begin{array}{c}\text { Bashkirskaya } \\
28 \\
\end{array}$ & 6.30 & Izhevskaya 2 & 7.76 \\
\hline Krupnozernaia 2 & 6.4 & $\begin{array}{c}\text { Bezenchukskaya } \\
380\end{array}$ & 6.91 & Vatan & 6.49 & Gorka & 8.66 \\
\hline Average & 24.44 & & 6.98 & & 6.61 & & 7.88 \\
\hline$X \max -X \min$ & 38.6 & & 0.44 & & 0.55 & & 1.68 \\
\hline
\end{tabular}

The above implies the development of technologies for the selection of specialized varieties depending on the purpose of grain use. Thereby, it is necessary to create a selection source material for varieties of each specialization, which will differ in grain quality; study the inheritance of selected characteristics, and determine the selection methods.

There has been discovered a high correlation between the quantitative content of water-soluble pentosans and the viscosity of the water extract of rye grain meal $[13, p$. 5]. It was found that starch and protein do not affect the viscosity of the water extract. It almost completely $(r=0.97)$ depends on the content of water-soluble arabinoxylans in it. Based on this, it is possible to predict the content of water-soluble pentosans not directly, but indirectly. It can be done by measuring the viscosity of water extract of rye flour using high-precision viscometers [14, p. 28], [15, p. 984]. The water extract viscosity of grain meal makes it possible to evaluate both the baking qualities and the feed advantages of rye grain. Currently, a number of authors have experimentally confirmed the possibility of reliable and rapid prediction of baking and feed qualities of rye by the extracted viscosity, which is very important in breeding work.

In addition to the variety, the content of water-soluble pentosans and the level of the water extract viscosity are greatly influenced by environmental factors: soil type, cultivation technology, harvesting time, storage conditions, and the amount of precipitation after rye heading. The lowest WSP and WEV indicators are observed when the grainfilling period takes place in optimal and medium-arid weather conditions [16, p. 33].

\section{Methods}

Studies of grain samples of winter rye were conducted in the experimental fields of the Chishminsky plant breeding center of the Bashkir Scientific Research Institute of Agriculture Subdivision of the Ufa Federal Research Center of the Russian Academy of Sciences in the pre-Ural steppe zone of the Ural region in 2016-2018. The research targets were 3 promising varieties of their own selection and 2 from the collection of the All-Russian Plant Growing Institute. The material for research was grown annually in an isolated field of crop rotation. Grain for analysis was grinded in a laboratory mill. The WSP content in winter rye samples was determined using the method of A. I. Ermakov. The main idea of the method is to exclude alcohol-soluble sugars from the analysis. Protein content was tested by the Kjeldahl method [18]. To determine the dynamic viscosity of the water extract of grain meal, a capillary viscometer VPZh-1 with a capillary diameter of $1.52 \mathrm{~mm}$ (the range of viscosity measurement from 60 to 300) was used and evaluated using the method of A. A. Goncharenko [19]. The kinematic viscosity of the water extract was calculated in centistokes using the formula:

$$
V=g / 9,807 \times T \times K,
$$

where $K$ is the viscometer constant, $\mathrm{mm}^{2} / \mathrm{s}^{2}$;

$V$ is kinematic viscosity, $\mathrm{mm}^{2} / \mathrm{s}$;

$T$ is the flow time, s;

$g$ is free fall acceleration at the measurement point, $\mathrm{m} / \mathrm{s}^{2}$.

With an internal capillary diameter of $1.52 \mathrm{~mm}$, the viscometer constant is $0.3617 \mathrm{~mm}^{2} / \mathrm{s}^{2}$.

The weight per 1000 kernel was determined according to the Russian standard GOST 12042-80, the natural weight was found according to GOST 10840-2017.

\section{Results}

Depending on the variety and conditions of grain formation, the content of water-soluble pentosans over the years of research was $1.43-3.06 \%$ per dry grain substance (table 1).

The WSP content among varieties in 2016 ranged from $1.50 \%$ (Kombaynnyay 3 variety) to $3.06 \%$ (Pamyati Kunakbaeva), in 2017 from $1.43 \%$ (Krupnozernaya 2) to $2.96 \%$ (Pamyati Kunakbaeva), in 2018 from 1.52 \% (Krupnozernaya 2) to $2.92 \%$ (Chulpan 7). For an average of 3 years, Pamyati Kunakbaeva variety had the highest content of water-soluble pentosans in grain $(2.97 \%$ ) while Kombaynnyay 3 and Krupnozernaya 2 varieties had the lowest WSP content $(1.48 \%)$ and $(1.52 \%)$. Chulpan 7 and Chulpan 9 varieties occupied an average position (2.38\% and $2.53 \%$, respectively). In 2018 Pamyati Kunakbaeva had particularly high WSP content in grain $(3.06 \%)$.

As a result of determining the viscosity of the water extract of the material under study, there was a strong difference in varieties and years. Among the selection material there are samples that differ significantly in the specified feature. The range of the solution viscosity varied from 5.3 to $45.0 \mathrm{cSt}$ (table 1). For 3-year average Pamyati Kunakbaeva variety had the highest water extract viscosity of grain $(45.0 \mathrm{cSt})$. The samples of Krupnozernaya 2 (6.4 cSt) and Kombaynnyay 3 (6.9 cSt) had the lowest values of the pentosan extracted viscosity. Pamyati Kunakbaeva had the highest grain water extract viscosity $(45.0 \mathrm{cSt})$ 


\begin{tabular}{|c|c|c|c|c|}
\hline & & The result & oratory analysi & ater rye san \\
\hline Variety & Year & 1000 kernel weight, $g$ & Grain unit, $g / l$ & Protein, \% \\
\hline \multirow{4}{*}{ Chulpan 7} & 2016 & 27.0 & 658 & 11.70 \\
\hline & 2017 & 29.3 & 697 & 11.53 \\
\hline & 2018 & 24.5 & 658 & 11.73 \\
\hline & Average & 26.9 & 671 & 11.65 \\
\hline \multirow{4}{*}{ Chulpan 9} & 2016 & 25.8 & 670 & 11.82 \\
\hline & 2017 & 28.9 & 658 & 11.76 \\
\hline & 2018 & 26.6 & 635 & 12.32 \\
\hline & Average & 27.1 & 654 & 11.97 \\
\hline \multirow{4}{*}{ Pamyati Kunakbaeva } & 2016 & 31.1 & 706 & 12.60 \\
\hline & 2017 & 27.5 & 641 & 11.82 \\
\hline & 2018 & 23.0 & 656 & 12.00 \\
\hline & Average & 27.2 & 668 & 12.14 \\
\hline \multirow{4}{*}{ Kombaynnyay 3} & 2016 & 24.1 & 611 & 14.72 \\
\hline & 2017 & 27.8 & 630 & 13.80 \\
\hline & 2018 & 26.5 & 630 & 14.58 \\
\hline & Average & 26.1 & 624 & 14.37 \\
\hline \multirow{4}{*}{ Krupnozernaya 2} & 2016 & 26.4 & 638 & 14.25 \\
\hline & 2017 & 27.1 & 650 & 13.50 \\
\hline & 2018 & 26.0 & 630 & 14.50 \\
\hline & Average & 26.5 & 648 & 14.08 \\
\hline
\end{tabular}

There was found a high correlation between the quantitative content of water-soluble pentosans and the viscosity of the water extract of rye grain meal $(r=0.98)$.

WSP and WEV values of winter rye strongly depend on the conditions of the growing season. They are significantly affected by the amount of precipitation during the grain filling and maturation. In the years of research, the climatic conditions during the vegetation period of plants were different. In 2016, there was a shortage of precipitation throughout the growing season, being confirmed by a very low value of the hydrothermal coefficient $(\mathrm{HTC}=0.7)$. High temperature and dry weather conditions during grain filling caused the early drying of plants. During the 2017 growing season, the air temperature was below the annual average with precipitation above normal $(\mathrm{HTC}=1.4)$. The cold, rainy summer significantly limited the grain development and filling. The growing season of 2018 was quite dry $(\mathrm{HTC}=0.9)$. The summer drought did not contribute to the good development of plants and grain filling. Within the same variety, the grain water extract viscosity varied over the years.

In a rainy year, all samples tended to have lower WSP and WEV values. It makes possible to conclude that the viscosity potential of rye increases significantly in dry years and decreases in wet years.

Winter wheat, spring wheat, and triticale were taken for comparative evaluation of the extracted viscosity of winter rye with various grain crops (table 2).

The conducted studies showed that winter rye had the highest viscosity potential $(24.44 \mathrm{cST})$, and winter wheat had the lowest viscosity potential (6.98 CST). On this basis, rye exceeded winter wheat by 3.5 times, spring wheat by 3.7 times, and winter triticale by 3.1 times. The greatest differences between varieties were observed in winter rye ( $38.6 \mathrm{cST})$, and the smallest in winter and spring wheat $(0.44-0.55 \mathrm{cST})$.
Structural analysis of the grain material showed that Kombaynnyay 3 (624 g/l) and Krupnozernaya 2 (648 g/l) varieties had the lowest grain unit (table 3).

For a 3-year average, the weight per 1000 kernel ranged from $26.10 \mathrm{~g}$ to $27.2 \mathrm{~g}$. All the studied varieties had a weight per 1000 kernel at a level below the average (less than $28 \mathrm{~g}$ ). Kombaynnyay 3 (26.1 g) and Krupnozernaya 2 (26.5 g) had the lowest weight per 1000 kernel.

On average over the years of the study protein content in grain among varieties was $11.65-14.37 \%$ per dry substance. In the years of research, this indicator was the highest in the samples of Kombaynnyay 3 (14.37\%) and Krupnozernaia $2(14.08 \%)$. In a wet year, the protein content was slightly lower than in dry conditions. It was found that the samples with lower WSP and WEV indicators had small grains, low grain unit and higher protein content.

\section{Discussion and Conclusion}

Based on the results of the conducted research the following conclusions can be made:

1. The main indicators of feed quality of winter rye grain (low content of water-soluble pentosans and high protein content) are caused not only by genotypic (varietal), but also by phenotypic (environmental) factors.

2. The content of WSP and WEV are unstable indicators and have a variable nature.

3. Kombaynnyay 3 and Krupnozernaia 2 had the lowest WSP and WEV values, along with high protein content in grain. These varieties can be classified as those for feed use.

4. The water extract viscosity is in linear dependence on the WSP content $(r>0.97)$.

5. The rye water extract viscosity tends to increase in arid years, and decrease in wet years. 
6. Winter rye had higher water extract viscosity than winter wheat by 3.5 times, spring wheat by 3.7 times, and winter triticale by 3.1 times.
7. It was found that the samples with lower WSP and WEV indicators had small grains, low grain unit and higher protein content.

\section{References}

1. Lavrent'eva N. S., Kuznetsova L. I., Kobylyanskiy V. D. Ispol'zovaniye muki iz zerna nizkopentozanovoy rzhi v tekhnologii khleba [Using low pentosan rye flour in bread production technology] // Problems of nutrition. 2018. No. 5. Pp. 225-226. (In Russian.)

2. Gaysin V. F., Nigmatullin N. G., Nurushev R. A., Akhiyarov B. G. Optimizatsiya fiziko-khimicheskikh i agrofizicheskikh svoystv chernozema opodzolennogo priyemami khimicheskoy melioratsii [Improving physical, chemical and agrophysical properties of black soil by chemical reclamation methods] // Sotsialno-ekonomicheskie problem razvitiya agrarnoy sfery ekonomiki i puti ikh resheniya: sbornik statei Vserossiiskoynauchno-prakticheskoy konferentsii, posviashchennoi 85-letiyu Bashkirskogo gosudarstvennogo agrarnogo universiteta. Ufa, 2015. Pp. 410-414. (In Russian.)

3. Filippova V. A., Kruglov Yu. V., Andronov E. E. Filogeneticheskaya struktura soobshchestva prokariot dernovo-podzolistoy pochvy pod ozimoy rozh'yu ne zavisit ot agrotekhnicheskikh priyemov [The phylogenetic structure of the prokaryotic community of sod-podzolic soil under winter rye does not depend on agrotechnical methods] // Selskokhozyaystvennaya biologiya. 2018. No. 5. Pp. 994-1003. DOI: 10.15389/agrobiology.2018.5.994rus. (In Russian.)

4. Rysev M. N., Volkova E. S., Fedotova E. N., Dyatlova M. V. Zakonomernosti deystviya udobreniy pod ozimuyu rozh' na dernovo-podzolistykh pochvakh [Regularities in the effect of fertilizers for winter rye on sod-podzolic soils] // Izvestiya Velikolukskoy gosudarstvennoy selskokhoziaistvennoy akademii. 2018. No. 4. Pp. 18-19. (In Russian.)

5. Akhiyarova L. M., Akhiyarov B. G. Ispol'zovaniye zerna ozimoy rzhi na kormovyye tseli [Using winter rye grain for feed purposes ] // Vklad molodykh uchenykh v innovatsionnoe razvitie APK Rossii: sbornik statey Mezhdunarodnoy nauchnoprakticheskoi konferentsii molodykh uchenykh, posvyashchennaya 65-letiyu FGBOU VO Penzenskata GSKhA. Penza, 2016. Pp. 37-40. (In Russian.)

6. Akhiyarova L. M., Akhiyarov B. G. Kormovaya tsennost' zerna ozimoy rzhi v zavisimosti ot prirodnykh usloviy Respubliki Bashkortostan [Feed value of winter rye grain depending on the natural conditions of the Republic of Bashkortostan] // Konyaevskie chteniya. V Yubileynaya mezhdunarodnaya nauchno-prakticheskaya posvyashchennoy 100-letiyu so dnya rozhdeniya vydayushchegosia uchenogosya i pedagoga, doktora selskokhoziaistvennykh nauk, professora, zasluzhennogo deyatelya nauki RSFSR Konyaeva Nikolaya Fedorovicha. Ekaterinburg, 2016. Pp. 301-304. (In Russian.)

7. Ismagilov R. R., Gaysina L. F., Ahiyarova L. M., Ayupov D. S., Nurlygayanov R. B., Akhiyarov B. G., Abdulvaleev R. R., Malyutina K. V., Ismagilov K. R., Abdulloev V. K. Crop yields and baking qualities of winter rye hybrids grain in the foreststeppe of the Republic of Bashkortostan // Journal of Engineering and Applied Sciences. 2018. Vol. 13. No. 8. Pp. 6487-6493. 8. Valitov A. V., Abdullin M. M., Akhiyarov B. G., Barakov A. U. Produktivnos' kormovykh kul'tur v zelenom konveyyere [Productivity of fodder crops in the green forage chain] // Vklad molodykh uchenykh v innovatsionnoe razvitie APK Rossii: sbornik statei Mezhdunarodnoy nauchno-prakticheskoy konferentsii molodykh uchenykh, posvyashchennaya 65-letiyu FGBOU VO Penzenskaya GSKhA. Penza, 2016. Pp. 32-34. (In Russian.)

9. Kondratenko E. P., Konstantinova O. B., Soboleva O. M., Izhmulkina E. A., Verbitskaya N. V., Sukhikh A. C. Soderzhaniye belka i aminokislot v zerne ozimykh kul'tur, proizrastayushchikh na territorii lesostepi yugo-vostoka Zapadnoy Sibiri [The content of protein and amino acids in the grain of winter crops growing on the territory of the forest-steppe of the South-East of Western Siberia] // Khimiya rastitelnogo syria. 2015. No. 3. Pp. 143-150. DOI: 10.14258/jcprm.201503754. (In Russian.)

10. Akhiyarova L. M., Ismagilov R. R., Malyutina K. V. Zavisimost' kormovoy tsennosti zerna ozimoy rzhi ot prirodnykh usloviy [Dependence of the feed value of winter rye grain on natural conditions ] // Materialy mezhdunarodnoy nauchno-prakticheskoy konferentsii, posvyashchennoy 85-letiyu Bashkirskogo gosudarstvennogo agrarnogo universiteta, v ramkakh XXV Mezhdunarodnoi spetsializirovannoi vystavki “Agrokompleks-2015”. Ufa, 2015. Pp. 39-44. (In Russian.)

11. Ponomareva M. L., Ponomarev S. N., Tagirov M. Sh., et al. Genotipicheskaya izmenchivost' soderzhaniya pentozanov v zerne ozimoy rzhi [Genotypic variability of pentosan content in winter rye grain] // Selskokhozyaystvennaya biologiia [Agricultural biology]. 2017. No. 5. Pp. 1041-1048. DOI: 10.15389/agrobiology.2017.5.1041rus (In Russian.)

12. Chotinsky D. The use of enzymes to improve utilization of nutrient in poultry diets // Bulgarian Journal of Agricultural Science. 2015. Vol. 21. No. 2. Pp. 429-435.

13. Ismagilov R. R., Gaysina L. F. Sravnitel'naya otsenka khlebopekarnykh kachestv zerna i gibridov ozimoy rzhi [Comparative assessment of baking qualities of winter rye and hybrid grain ] // Grain economy of Russia. 2015. Vol. 41. No. 5. Pp. 1-7. (In Russian.)

14. Goncharenko A. A. Novyye napravleniya v selektsii ozimoy rzhi na tselevoye ispol'zovaniye [New directions in the selection of winter rye for targeted use] // Zernobobovye i krupyanye kul'tury. 2016. No. 2 (18). Pp. 25-31. (In Russian.)

15. Stepniewska S., Slowik E., Cacak-Pietrzaketc G. Prediction of rye flour baking quality based on parameters of swelling curve // European Food Research and technology. 2018. Vol. 244. Pp. 989-997.

16. Ponomareva M. L., Ponomarev S. N., Gil'mullina L. F., Mannapova G. S. Fenotipicheskaya otsenka soderzhaniya pentozanov v rzhanom shrote metodom opredeleniya vyazkosti vodnogo ekstrakta [Phenotypic assessment of the content of pentosans 
in rye meal by determining the viscosity of an aqueous extract] // Dostizheniia nauki i tekhniki APK [Achievements of science and technology of the agro-industrial complex]. 2015. No. 11. Pp. 32-35. (In Russian.)

17. Boros D. Extract Viscosity as an Indirect Assay for Water-Soluble Pentosan Content in Rye // Cereal Chemistry.1993. Vol. 70. No. 5. Pp. 575-580.

18. Ermakov A. I. Metody biokhimicheskikh issledovaniy rasteniy [Methods of biochemical research of plants]. Third edition, revised and added. Leningrad, 1987. 430 p. (In Russian.)

19. Goncharenko A. A., Timoshchenko A. S. Opredelenie dinamicheskoy vyazkosti vodnogo ekstrakta zernovogo shrota ozimoy rzhi s pomoshch'yu kapillyarno-protochnogo viskozimetra: metodicheskie rekomendatsii [Determining the dynamic viscosity of an aqueous extract of winter rye grain with a capillary-flow viscometer: methodical recommendations]. Moscow, 2005. (In Russian.)

\section{Authors'information:}

Anvar Kh. Shakirzyanov ${ }^{1}$, doctor of agricultural sciences, senior researcher, ORCID 0000-0002-8258-0648, AuthorID 158704; +7917430-31-59, shakirzyanof@yandex.ru

Ilyusya M. Nikonorova ${ }^{1}$, chief agronomist, ORCID 0000-0001-6883-7593, AuthorID 178024; +7 937 837-93-80,

ilyusya.nikonorova@mail.ru

Viktoriya A. Agafonova ${ }^{1}$, chief agronomist, ORCID 0000-0002-7293-3200, AuthorID 1028429; +7 937 359-92-02, a.v.a2016@mail.ru

${ }^{1}$ Bashkiria Research Agricultural Institute, Ufa Federal Research Center of the Russian Academy of Sciences, Ufa, Russia 